\title{
IMPOLITENESS STRATEGIES AND POWER PERFORMED BY NETIZENS ON TWITTER
}

\author{
By: \\ Rugun Mastiar Pangaribuan 1) \\ Rahmadsyah Rangkuti ${ }^{2)}$ \\ Roma Ayuni Lubis ${ }^{3}$ \\ University of Sumatera Utara (USU), Medan 1,2,3) \\ E-mail: \\ $\frac{\text { rugunmastiarp@gmail.com }}{{ }^{1)}}$ \\ romaloebis@gmail.com $^{3)}$
}

\begin{abstract}
This study aims at finding out the impoliteness strategy used by netizens in commenting on actor's tweets and the forms of tweet comments made by netizens. This study employs a descriptive qualitative method. The sources of data were tweeted by Jefri Nichol, one of the famous actors in Indonesia. In analyzing the data, the Theory of Culpeper (1996) describes the kinds of impoliteness strategies that netizens used in their tweet comments. This research shows that there are five data of tweet comments categorized into four types: bald on record impoliteness, positive impoliteness, negative impoliteness, and sarcasm or mock politeness. This research uses the Theory of Beebe (1995) and Bousfield (2008) for power performed, which categorized as superior, get authority over actions, dominate a conversation, emphasize the power hierarchy, and reactivate the power. The findings show that the netizens are angry and uncomfortable with Jefri's tweet because his tweet was like carrying someone's physical or face, where the things like this are a sensitive topic.
\end{abstract}

Keywords: Impoliteness Strategies, Power, Twitter, Netizen.

\section{Introduction}

Scollon and Scollon (2001) confirmed that impoliteness is an exercise of power in which it would be easily performed by those who have power which boots their confidence of being impolite. Impoliteness is not only performed in verbal communication but also written form of social media. Because of social media, there is no place to hide the information so that the information spreads very easily and fast. Social media gives some data on how people use their language through captions or comments on Facebook, Twitter, Instagram, and Line.

The object that analyzes by the researcher is the tweets from Indonesian actor Jefri Nichol. Both the tweets and netizens' replies from his tweets contain sentencesof impoliteness. Netizens use impoliteness words that are not rude but also use nasty words that are not supposed to. The theory used for this topic is Culpeper (1996). Culpeper describes five super strategies: bald on record impoliteness, positive impoliteness, negative impoliteness, sarcasm or mock impoliteness, and withhold impoliteness.

\section{Literature Review \\ 2.1 Impoliteness}

Yule (1996:59), in his book, argued that using language is not only doing linguistic inter-action but also social interaction. Inability to communicate politely in social interaction may harm the speaker and the interlocutor. Social disharmony becomes one of the harmful impacts. Considering the importance of polite communication, the knowledge regarding polite and impolite communications needed. To understand 
more deeply politeness and impoliteness, one needs to study linguistics. Pragmatics is one branch of linguistics that examines politeness and impoliteness. Impoliteness strategies proposed by Culpeper (1996: 365-357) can be described as follows.

\section{- Bald on Record Impoliteness}

Action threatening the face of the speech partner directly, clearly, unambiguously, and concisely when the face is irrelevant or minimized. It does not need to be connected face to face. (Example: Your t-shirt is ugly!)

\section{- Positive Impoliteness}

The use of that strategy is intended to damage the cheerful face of the listener or partner. Culpeper 1996:357 states that the realizations of positive impoliteness are disassociating from the others, calling the other names, utilizing taboo words, and using inappropriate identity markers (Example: Hey drunkard, since when do you care about my problems?)

\section{- Negative Impoliteness}

The strategy use aims to damage the opposing face of the listener or partner. This strategy includes condescending/scorning/ridiculing, associating the other with a negative aspect explicitly, and invading the other's space. (Example: A: Can you explain this to me / B: Stupid! Even that, you do not understand!)

\section{- Sarcasm or Mock Politeness}

Performed with the use of politeness strategies that are obviously insincere and thus remain surface realizations. Both strategies are the same, performing impolite utterances because of insincere intention. It is heavily related to the context, and it is surface politeness that can be interpreted in an impolite way because of certain contextual clues and the intention of not offending but rather to show social intimacy. Often one has to know the person well in order to understand that he is sarcastic, mocking, or joking. (Example: "Oh, your shirt is gorgeous!" (When in reality they find it ugly)

\section{- Withhold Politeness}

Not doing strategy politeness as expected.For example, forget to say thank you to partners who give gifts or congratulations. Culpeper (1996: 357) notes that impoliteness may be realized through "...the absence of politeness work where it would be expected." Then, Culpeper (2005: 42) gives an example that "failing to thank someone for a present may be taken as deliberate impoliteness. (Example: A: Are you okay? / B: (silent))

\subsection{Power}

Influential people have the freedom to make themselves impolite participants in the conversation. According to Lakoff and Penman cited by Culpeper, it all happens because it reduces the ability of the less powerful participant to retaliate with impoliteness (e.g., through the denial of speaking rights) and threaten more severe retaliation should the less powerful participant be impolite. Power in here means when someone does communication directly (face to face) or through social media.

The researchersget the theory from Beebe (1995) and Bousfield (2008) to find out how power and impoliteness relate. Beebe (1995) argues that there are three purposes of exercising power. The first purpose is that the more powerful speaker wants to appear superior. This purpose is applied when the speaker feels the power and tries to use the sentence impolitely to prove to the other person that he/she has power. The second purpose is when the more powerful speaker wants to get authority over actions. This purpose is applied when people who have power ask the other person to follow the right words and avoid something wrong by using impoliteness. The third purpose is to dominate a conversation. This purpose is applied to another person, not to connect someone who has power or silence. The people also use impoliteness.

Bousfield (2008a) mentions two purposes of the exercise of power through impoliteness. The first purpose is to 
emphasize the power hierarchy between the more powerful and more minor participants. In this case, people who have the power to speak clearly and unambiguously, so their words can be accepted or use impoliteness also in it. The second purpose is to reactivate the power. In this case, people have the power to reprimand the interlocutor when there are wrong words or sentences, and clarify as clearly as possible will not cause misunderstanding.

\subsection{Twitter}

Impoliteness always arises in social media, including Twitter. In this case, Twitter partakes as a medium in performing impoliteness to attack others publicly. Twitter is an information service that we can share with many people worldwide, where Twitter is one form of verbal communication set out in writing.

Twitter is currently a type of social network on the rise, popular from young people until older people. For example, artists/actors. It turns out that even artists/actors use Twitter accounts to criticize many things and often use them for self-image. That way, the freedom to comment directly and indirectly polite appearing in the community can lead to internal disharmony language, so there is often conflict and hostility due to impoliteness language in expressing threatening arguments on social media face directly and often use offensive language, even taboo condescending or insulting.

\subsection{Netizen}

Netizens are also human. They communicate to seek various entertainment and also information. The freedom of cyberspace also gives freedom to the people in it to voice their opinions and ideas. There are facilities in each country, namely the internet, to make it easier for citizens to express their opinions freely, such as social media, blogs, video sharing sites, and other sharing sites that netizens can use. Viral news has a profound effect on the role of netizens. Therefore, netizens want to keep the freedom and openness on the internet. When the government wants to regulate the internet, netizens strongly oppose and reject the plan.

\section{Research Method}

The type of study in this research is descriptive qualitative. The qualitative descriptive in this study is intended to produce data in the form of descriptions of the impoliteness of commenting on the Indonesian actor, Jefri Nichol. By this type of research, the data used are netizens' comments that show violations of decency. The source of data is the Indonesian artist tweet, Jefri Nichol in 2020, which can be seen on Twitter (https://twitter.com/jefrinichol). Jefri's tweets are the data in the form of sentences. Because of what is known, data can be in sentences, words, images, and others. The data used in this research are the netizen's replies to Jefri's tweets.

\section{Results and Discussion 4.1 Sub Chapter 1 (Analysis)}

\subsection{Sub Chapter 2 (Explanation of Each Data)}

a. Data 1

$$
\text { User Qyes (@YesQ19) }
$$

"Setahugue, orang yang gapunyatujuanhidupbiasanyanyabu" (As far as I know, people who don't have a purpose in life are usually addicted to crystal meth)

The form of the reply above shows that netizen feels annoyed about the tweet made by Jefri. The type of reply above is negative impoliteness. The sentence "people who don't have a purpose in life are usually addicted to crystal meth" netizen is ridiculing Jefri and bringing his drug case because netizen has a power hierarchy, speaks clearly, and sentences can be accepted. The case of Jefri, who was caught in drugs is valid.

\section{b. Data 2}

User Ilakkk (@apriliahnd)

"Gantengsukanarkobaapajugagunanya mending 
jelekgasukanarkobanarkobaanlol" (What's the use of being handsome but like drugs, better ugly but don't like drugs lol-_-)

The form of the reply above shows that netizenfeels disappointed about the tweet made by Jefri. The type of reply above is bald on record impoliteness. From the sentence "What's the use of being handsome but like drugs" netizens brings Jefri's case using the drugs and say there are no points in having a handsome face if already used drugs. The power used here appears superior. A netizen has power because the impact of drugs is terrible, especially in social life. If someone has been exposed to drugs, people will likely stay away from us and find difficulties to get a job because they have a record of drug users.

\section{c. Data 3}

User (@ Aminbadali20)

Anjingmanjatpohonkelapa

"Masnyacobanyabudulu, barang kali otaknyabisalebihbaikhehe"(He can try the meth first, maybe his brain can be better hehe)

The form of the reply above shows that netizenfeels disappointed about the tweet made by Jefri. The type of reply above is sarcasm or mock politeness. The sentence "He can try the meth first, maybe his brain can be better hehe" netizen insinuated Jefri regarding his drug case. The netizen says that using drugs would make Jefri's brain better, but the meaning because Jefri has a drug case. He has the power to dominate a conversation; comment like that because of the tweet made by him (Jefri) seem made a commotion, so he (netizen) suggested something by insinuating Jefri that he could be even better at making a tweet.

\section{d. Data 4}

User Odddl (@hayolaw)

"Sok bet gantengsianjing" (Acting all cool anjing)

The form of the reply above shows that netizenfeels anger about the tweet made by Jefri. The type of reply above is positive impoliteness. The netizen uses the taboo word (using the rude word) "anjing" in Bahasa is a rude word. The power that uses in here is to reactivate the power when there are wrong words/sentences. Then netizens can comment that because of the tweet from Jefri, which makes people misunderstand and many people curse at him, a netizen has not to feel guilty about it.

\section{e. Data 5}

User Cantik (@pelarryan)

“Asliguabanggabangetsamadiriguaseka rang,

untungnyaguagapernahngefanssamaludarij amanluterkenal di Dear Nathan. Proud of myself" (Surely, I'm really proud of myself now, luckily I've never been a fan of you since you were famous in Dear Nathan. Proud of myself)

The reply above shows that netizen has to feel angry and disappointed about the tweet made by Jefri. The type of reply above is sarcasm or mock politeness. From the sentence "Surely, I'm really proud of myself now, luckily I've never been a fan of you" it is proven that netizen do sarcasm to Jefri because she feels proud not to be part of the people who like Jefri (his fans). The netizen says that because she sees Jefri's tweet, which seems disrespectful and inappropriate to be a role model. Netizen uses power to get authority over actions by indirectly inviting other netizens not to become part of Jefri's fans, but the netizen says in sarcasm to convince other netizens to follow the right one.

\section{Conclusion}

Based on the data analysis and findings presented in the chapter four, there arefour types of impolitness strategies. There are 5 data on netizens' tweet comments found in the data source. In 5 data on netizens' tweet comments, the total of each impoliteness strategy as follows: Bald on Record Impoliteness (1 tweet comment), Positive Impoliteness (1 tweet comment), Negative Impoliteness (1 tweet comment), and Sarcasm or Mock Politeness (2 tweet comments). The 
withhold politeness strategy is not used because it is a strategy of impoliteness that netizens throw through social media, not face-to-face or in person, so it is difficult to know. These impoliteness strategies occur because of Jefri Nichol's tweets that carry the physical/face of a person, which is very sensitive to discuss. Many netizens also commented with bring his case who was caught in a drug case. Netizens utter harsh words and some even use taboo words.

Beside impoliteness, In 5 data on netizens' tweet comments, the total of each power as follows: Appear as Superior (1 tweet comment), Get Authority (1 tweet comment), Dominate a Conversation (1 tweet comment), Emphasize The Power Hierarchy (1 tweet comment), and Reactivate The Power (1 tweet comment).

\section{References}

Beebe, L. (1995). Polite fictions: Instrumental Rudeness as Pragmatic Competence in J. E. Alatis, C. A. Straehle, B. Gallenberger, \& R. Maggie, Linguistics and The Education of Language Teachers: Ethnolinguistic, Psycholinguistic and Sociolinguistic Aspects (pp. 154-168). Georgetown: Georgetown University Press.

Bousfield, D. (2008). Impoliteness in Interaction. Philadelphia: John Benjamins Publishing Company.

Bousfield, D. (2008). Impoliteness in Language. New York: Berlian.

Bousfield, D. (2008). Impoliteness

in The Struggle For Power in D. Bousfield\& M. A. Locher (Eds.), Impoliteness in Language: Studies on its Interplay With Power in Theory and Practice (pp. 127-154). Berlin, Germany: Mouton de Gruyter

Brown, Penelope and Stephen C. Levinson.Impoliteness in Interaction. Amsterdam: John Benjamins Publishing Company, 1992. Web.

Culpeper, J. (1996). Towards an Anatomy of Impoliteness.Journal of Pragmatics 25: 349-367.
Khatib, M., and Lotfi K. Impoliteness and Power: An Interlanguage Pragmatic Approachto the Use of Impolite Patterns in Terms of Power. Journal of English Language Teaching and Learning, 15 , pp. 4.

Miriam L., and Bousfield, D. 2008. Introduction: Impoliteness and Power in Language, Berlin : Mouton de Gruyter.

Yule, G. 1996. Pragmatics.Oxford : Oxford University Press. 